\title{
Outage Management and House of Quality to Improve Power Station Performance
}

\author{
Wahyu Rochmansyah ${ }^{1}$, Mokh. Suef ${ }^{2}$
}

\begin{abstract}
The Coal Power Plant from Fast Tracking Project (FTP) owned by PT ABC is built by contractors from China. PT $A B C$ is a company working in the area of the provision of electricity services business. In 2010 PT ABC establish business units new special serving the implementation of the operation \& maintenance unit whenever the business units services operation \& maintenance. Currently has been implement operation \& maintenance four units of steam power plants a large scale with, namely Coal Fired Power Plant Indramayu , Coal-Fired Power Plant Rembang, Coal Fired Power Plant Pacitan And Paiton New Coal Fired Power Plant, The condition of generating equipment is not good enough. Maintenance undertaken is currently inadequate again despite the condition of the equipment age is still young. The maintenance of the power plant is needed so that the power plant can improve the quality of service in order to meet the community's guidance and the challenges of technological development. To improve overhaul planning and preparedness at an optimum level, maintenance management is required using Outage Management, which is a synergistic and sustainable process of Planning, Monitoring, Controlling and Evaluation of Planed Outage and using House of Quality (HOQ). Outage Management is used to optimize power plant maintenance activities by applying the rules of Right Problem, Right Solution, Right Design, Right Implementation. By using House of Quality (HOQ), broadly voice of costumer attempted to be converted directly into technical characteristics of maintenance. By applying it is expected the company will be able to achieve technical characteristics in accordance with the target set. from attribute of quizoner made there is Priority Voice of customer (VOC) requirement to Critical Customer Requirements (CCR) are Safety Base Outage Management on Frame Outage Management on priority 1 with score 97 while Outage Management on score 72.
\end{abstract}

Keywords-Outage Management, HOQ, Maintenance, Power Plant, Voice of Customer.

\section{INTRODUCTION}

Coal Power Plant as Fast Tracking Project (FTP) owned by PT ABC is a product from China, with the construction price per MegaWatt relatively cheap compared to Japan, USA or Europe product. This cheap price is not directly related to reliability. Maintenance of power plants includes corrective, preventive and overhauled maintenance. Maintenance of power plants that are currently implemented are inadequate. Better overhaul planning and

\footnotetext{
${ }^{1}$ Wahyu Rochmansyah is with Java-Bali Power Generating Company (PT.PJB), West-Java, Indonesia. E-mail: wahyu.pltgu@gmail.com.

${ }^{2}$ Mokh. Suef is with Department of Industrial Engineering, Institut Teknologi Sepuluh Nopember, Surabaya, 60111, Indonesia. E-mail: mokhsuef@gmail.com.
}

preparedness needs to be made of maintenance management by applying the Outage Management and House of Quality (HOQ) tools. Outage Management is a synergy and sustainable process of Planning, Monitoring, Control and Evaluation of Planed Outage [1]. HOQ with QFD Method is used by to convert voice of costumer directly to technical characteristic or technical specification of a product (goods or service) that is produced so that company can try to achieve technical characteristic which is in accordance with expected target [2]-[4]. The aim of this research is to choose the right strategy to achieve the target of reliability and efficiency of the plant, to ensure continuity of scope in overhaul activity and to mapping the priority of Voice of customer requirement (VOC) to Critical Customer Requirements (CCR).

\section{Outage Management DatA}

Quality is the level of good or bad a product can be determined by 8 dimensions including performance, features, reliability, conformance, durability, serviceability, aesthetics and perceived. This study needs to know the actual conditions of the object under study with data based on the Simple Inspection Unit 1Indramayu Power Plant, with the following process results:

1. Pre outage phase: The process carried out before the shutdown unit where is an R1:1-18 months before the unit shut down, R 2 : 12 months before the unit shut down, and R3 : 6 months before the unit shut down during preparation P1: 3 months before the unit shut down, P2 :1 month before the unit shut down, and P3 : 1 week before the unit shut down in the process there is a proposed delay in the implementation of the original work 15 November - 20 December 2017 to 24 November - 29 December 2017 due to late delivery of spare parts valve (58 sets).

2. Outage execution phase: The process of carrying out the work of dismantling, checking and reinstalling. During the job execution process there are job findings so that it is done Revision 2 Shedule as November 28, 2017 Already Seen Large Large Size (Large Prediction of Small Stone). There was a revised Schedule Duration of OH Related Evacuation of Stone (Heavy Ash) from 36 Day Becomes 46 Days.

3. Post outage phase: the process after the overhaul by making Evaluation, Report, Recommendation \& Planning of $\mathrm{OH}$ results (1 month), there is an increase in boiler efficiency $86.3 \%$ to $86.4 \%$ and a decrease in turbine heat rate 2133 to $2089 \mathrm{Kcal} / \mathrm{Kwh}$ 
Collecting data by conducting questionnaires where respondents were asked to assess their performance and expectations for descriptions in the planning and implementation of overhauls which are grouped into likert scales (1-5) including performance appraisal and assessment of expectations for 12 customer requirements aspects of tangible, 11 customer requirements aspects of empathy, 3 customer customer requirement, 3 customer requirement reliability and 3 customer requirement aspect of assurance. Based on the questionnaire data processing obtained:

- performance value, highest in customer requirement no. 14 "The team leader or project manager participates in maintaining order while carrying out activities for the entire team" of 5.55 and the lowest is the customer requirement no. 7 that is "Condition of special tool equipment in good condition during use over haul is returned in good condition" amounted to 4.025 .

- The expectation value, the highest in the customer requirement number 3 "Overhaul is carried out with respect to compliance with environmental factors" of 4.85 and the lowest is at the customer requirement no. 18 "The executing personnel are concerned and obedient to all rules applicable in the Unit when doing over haul" of 3.475 .
- Highest customer satisfaction (maintenance service unit) customer requirement number 1 "Overhaul carried out by prioritizing safety factors being the main factor" of 4.45 and the lowest on customer requirement number 14 "Team leader or project manager helps maintain order when conducting activities against the whole team "is 2.1

\section{Description of TeChnical Response (Voice of the COMPANY)}

Description Technical response is the answer to customer needs where the result is the desire of the customer for the requirements needed. This technical response is derived from the description in the process of overhaul planning until the process of overhaul implementation, including 11 responses, namely outage management, safety golden rule, POB 5 S, KLHK Regulation and Environmental IK, Safety Golden Rule WEB Optimization Tool, PM Crane routine contract, Safety Base Outage Management, Work Planning \& Control, Internal Unit Regulations, Operational Performance Contracts and I-PJB Guidelines. The value of the relationship between 32 Customer Requirements and 11 Technical Respoms can be seen in Figure 1.

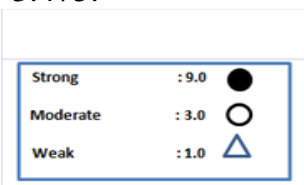

Customer Requirement

Overhaul penguatan faktor HSE

Overhaul dengan kaidah $5 \mathrm{~S}$

Overhaul kepatuhan faktor lingkungan

Overhaul dengan peralatan yang modern

Kondisi peralatan Crane

Kondisi sarana Air yang hemat

Kondisi peralatan special tool

Layout sesuai

Membuat tagging

Menyediakan tempatistirahat yang baik

Menyediakan portable toilet

Melaksanakan pekerjaan dengan peralatan lengkap

Ketua team atau manajer proyek faham pencapain kinerja unit

Ketua team atau manajer proyek ikut menjaga ketertiban di unit

Ketua team atau manajer proyek ikut menjaga ketertiban di luar unit

Ketua team atau manajer proyek melakukan kordinasi dan bekerjasama

Personil pelaksana bersikap sopan dan ramah

Personil pelaksana peduli dan patuh

Personil pelaksana cepat menanggapi keluhan dan temuan K3

Personil pelaksana Menjaga hubungan baik

Turut menjaga kebersihan di lingkungan pekerjaar

Personil pelaksana ikut merasa memiliki

Personil pelaksana melakukan kordinasi

Scope Pelaksanaan over haul sesuai dengan standart dan mutu

Melaksanakan semua pekerjaan sesuai dengan scope standart

Membuat melakukan Breakdown pekerjaan menjadi lebih detail

Posisi Team Overhaul tinggal dekat dengan unit

Personil Overhaul mudah dihubungi dan cepat respon

Jika ada peluang percepatan tetap dengan mutu dan kesesuaian standart

Kemampuan dalam menyelesaikan temuan

Tidak menunda pekerjaan temuan diluar scope overhaul

Menyelesaikan semua wo garansi pekerjaan saat pelaksanaan over haou Total

Ranking

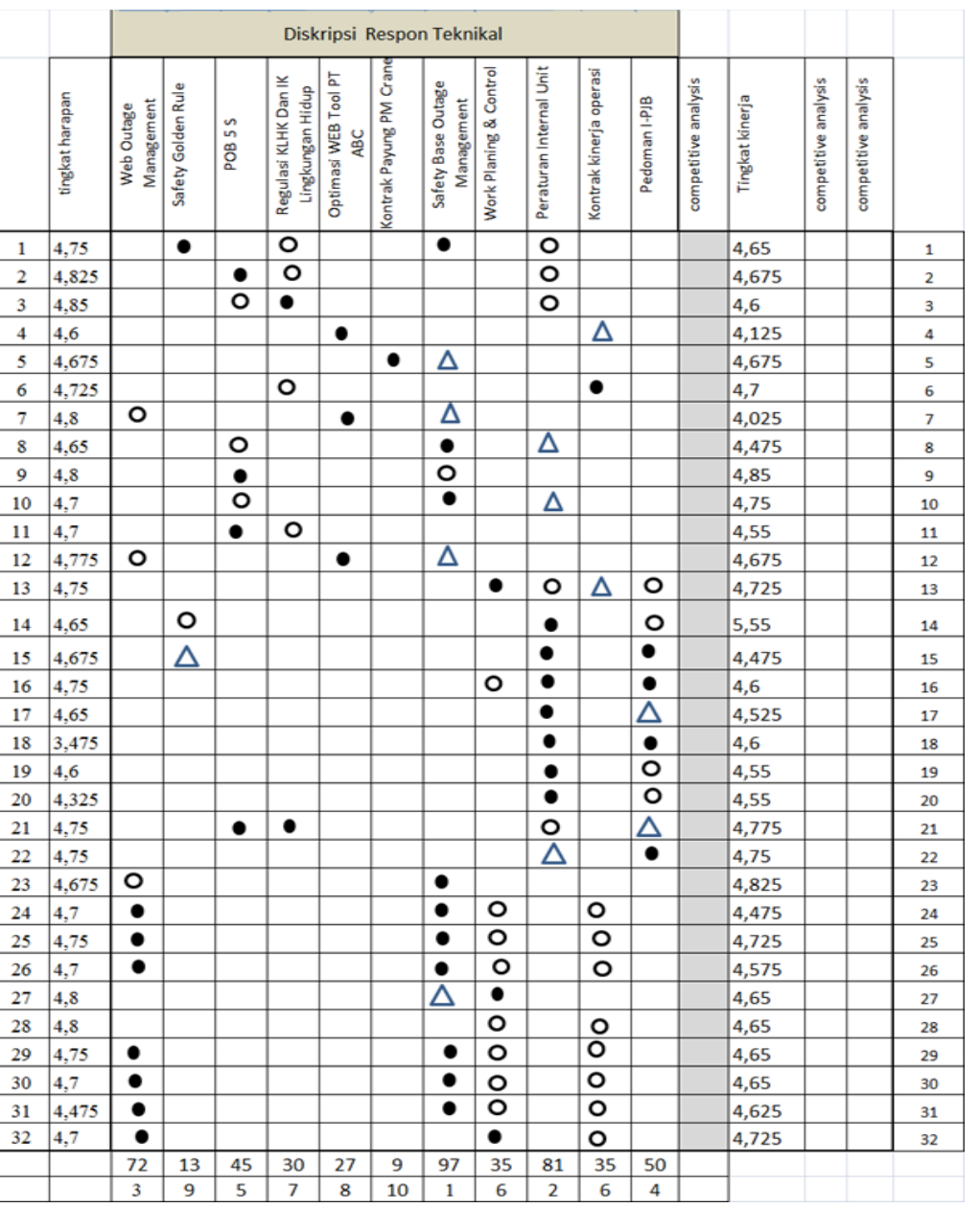

Figure 1. Value of Relationship between Customer Requirement and Technical Response 
Description Figure 1.

- : Strong Relation Between Technical Response and Description of service overhaul implementation, weighted value of linkage $=9$

o : Medium Relation Between Technical Response and Description of service overhaul implementation, weighting value of linkage $=3$

$\Delta$ : Weak relationship Between Technical Response and Description of service overhaul implementation, weighting value of linkage $=1$

Correlation Relation between Technical Requirements is shown in Figure 2. The 3rd highest Technical Response rank is customer requirement no 1 for 97, customer requirement no 2 worth 81 and web outage management worth 72.

\section{SERVQUAL SCORE}

Servqual score is an assessment to find out globally whether the topic is discussed whether it meets customer needs or not. If the value of the servqual score is positive then the topics covered meet the needs of customers in general, while the negative servqual score then the topic discussed does not meet the needs of customers in general in this case should be followed up. A positive servqual score is obtained at customer requirement no 5, 9, 10, 14, 18, 20, 21, 22, 23, 31 and 32. Another customer requirement is negative so that follow-up is required. Details of the acquisition value can be seen in Table 1.

\section{CONCLUSION}

That from the results obtained and from the stage of data processing to the stage of data analysis can be concluded, the implementation of overhaul with research objectives to choose the right strategy to do in achieving the target (Reliability and High Efficiency Unit) and ensure the continuity of scope and activities Overhaul safely is to implement in accordance with outage management frames by adding Safety Base Outage Management strategy to PT ABC Frame Outage Management and if there are findings related to the procurement of spare parts or findings during operation, from attribute of quizoner made there is Priority Voice of customer (VOC) requirement to Critical Customer Requirements (CCR) are Safety Base Outage Management on Frame Outage Management on priority 1 with score 97 while Outage Management on score 72.

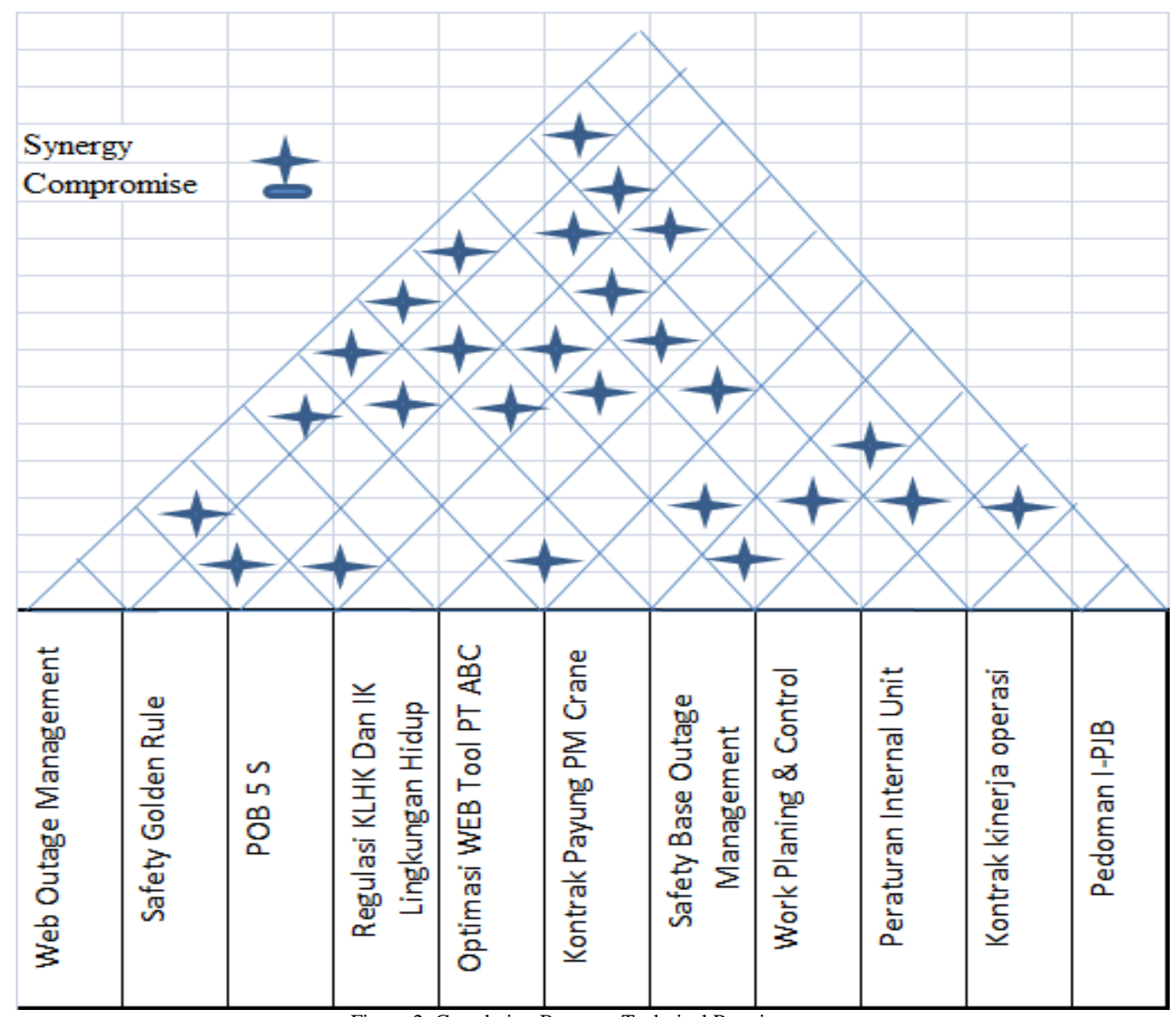

Figure 2. Correlation Between Technical Requirements 
TABLE 1.

SERVQUAL SCORE

\begin{tabular}{|c|c|c|c|c|}
\hline NO & Description & Interest level & $\begin{array}{l}\text { Satisfaction } \\
\text { Level }\end{array}$ & $\begin{array}{l}\text { Servqual } \\
\text { Score }\end{array}$ \\
\hline 1 & HSE factor improvement & 4,65 & 4,75 & $-0,1$ \\
\hline 2 & Overhaul with 5S rules & 4,675 & 4,825 & $-0,15$ \\
\hline 3 & Improvement of environmental factors & 4,6 & 4,85 & $-0,25$ \\
\hline 4 & Revamp with modern equipment & 4,125 & 4,6 & $-0,475$ \\
\hline 5 & Condition of Crane equipment & 4,675 & 4,675 & 0 \\
\hline 6 & Conditions for efficient water facilities. & 4,7 & 4,725 & $-0,025$ \\
\hline 7 & Conditions for special equipment & 4,025 & 4,8 & $-0,775$ \\
\hline 8 & Layout is appropriate & 4,475 & 4,65 & $-0,175$ \\
\hline 9 & Make tagging & 4,85 & 4,8 & 0,05 \\
\hline 10 & Provides a good resting place & 4,75 & 4,7 & 0,05 \\
\hline 11 & Provides portable toilets & 4,55 & 4,7 & $-0,15$ \\
\hline 12 & Carry out complete equipment work & 4,675 & 4,775 & $-0,1$ \\
\hline 13 & $\begin{array}{l}\text { The team leader or project manager understands } \\
\text { unit performance achievement }\end{array}$ & 4,725 & 4,75 & $-0,025$ \\
\hline 14 & $\begin{array}{l}\text { The team leader or project manager joins the } \\
\text { appointment in the unit }\end{array}$ & 5,55 & 4,65 & 0,9 \\
\hline 15 & $\begin{array}{l}\text { The team leader or project manager participates } \\
\text { in maintaining the unit outside }\end{array}$ & 4,475 & 4,675 & $-0,2$ \\
\hline 16 & $\begin{array}{l}\text { The team leader or project manager coordinates } \\
\text { and performs }\end{array}$ & 4,6 & 4,75 & $-0,15$ \\
\hline 17 & A person who is polite and friendly & 4,525 & 4,65 & $-0,125$ \\
\hline 18 & Implementing personnel care and obey & 4,6 & 3,475 & 1,125 \\
\hline 19 & Inauguration meeting and K3 meeting & 4,55 & 4,6 & $-0,05$ \\
\hline 20 & Implementing personnel Maintain good relations & 4,55 & 4,325 & 0,225 \\
\hline 21 & Hygiene care in the work environment & 4,775 & 4,75 & 0,025 \\
\hline 22 & Implementing personnel also have ownership & 4,75 & 4,75 & 0 \\
\hline 23 & Implementing personnel coordinate & 4,825 & 4,675 & 0,15 \\
\hline 24 & $\begin{array}{l}\text { The scope of implementation of over haul in } \\
\text { accordance with standards and quality }\end{array}$ & 4,475 & 4,7 & $-0,225$ \\
\hline 25 & $\begin{array}{l}\text { Carry out all work in accordance with the } \\
\text { standard scope }\end{array}$ & 4,725 & 4,75 & $-0,025$ \\
\hline 26 & Make Job details more detailed. & 4,575 & 4,7 & $-0,125$ \\
\hline 27 & Team Overhaul's position lives close to the unit & 4,65 & 4,8 & $-0,15$ \\
\hline 28 & $\begin{array}{l}\text { Personnel overhaul is easy to contact and respond } \\
\text { quickly }\end{array}$ & 4,65 & 4,8 & $-0,15$ \\
\hline 29 & $\begin{array}{l}\text { If there is a chance of permanent acceleration with } \\
\text { a standard of conformity and suitability }\end{array}$ & 4,65 & 4,75 & $-0,1$ \\
\hline 30 & Ability to complete findings & 4,65 & 4,7 & $-0,05$ \\
\hline 31 & $\begin{array}{l}\text { There is no need to look for work waiting for } \\
\text { repairs to the scope }\end{array}$ & 4,625 & 4,475 & 0,15 \\
\hline 32 & $\begin{array}{l}\text { Complete all work guarantees when implementing } \\
\text { over haouls }\end{array}$ & 4,725 & 4,7 & 0,025 \\
\hline & Serqual Total Score & & & $-0,875$ \\
\hline & Average Serqual Score & & & $-0,027344$ \\
\hline
\end{tabular}

\section{REFERENCES}

$[1]$

PT. PJB, Outage Management. Jawa Bali Power Generation Company, 2004.

[2] J. L. Bossert, Quality function deployment: a practitioner's approach. New York: Marcel Dekker, 1991.
[3] D. Maritan, Practical manual of quality function deployment. New York: Springer, 2015.

[4] L. Cohen, Quality function deployment : how to make QFD work for you. Reading, Massachusetts: Addison-Wesley, 1995. 